\title{
Mapping glacial rock flour deposits in Tasersuaq, southern West Greenland
}

\author{
Ole Bennike*1, Jørn Bo Jensen ${ }^{1}$, Frederik Næsby Sukstorf ${ }^{2}$ and Minik T. Rosing ${ }^{3}$
}

RESEARCH ARTICLE | OPEN ACCESS

GEUS Bulletin Vol 43 | e2019430206 | Published online: 17 July 2019

https://doi.org/10.34194/GEUSB-201943-02-06

Global population has increased rapidly in recent decades. So far, it has been possible to feed the growing population by using more and more land for agriculture, using irrigation and artificial fertilisers and by improving the efficiency of agriculture. Recently the growth of the global agricultural area has slowed. However, the need for food will continue to grow markedly in coming years. This demand can no longer be met by using increasingly more land for agriculture, and

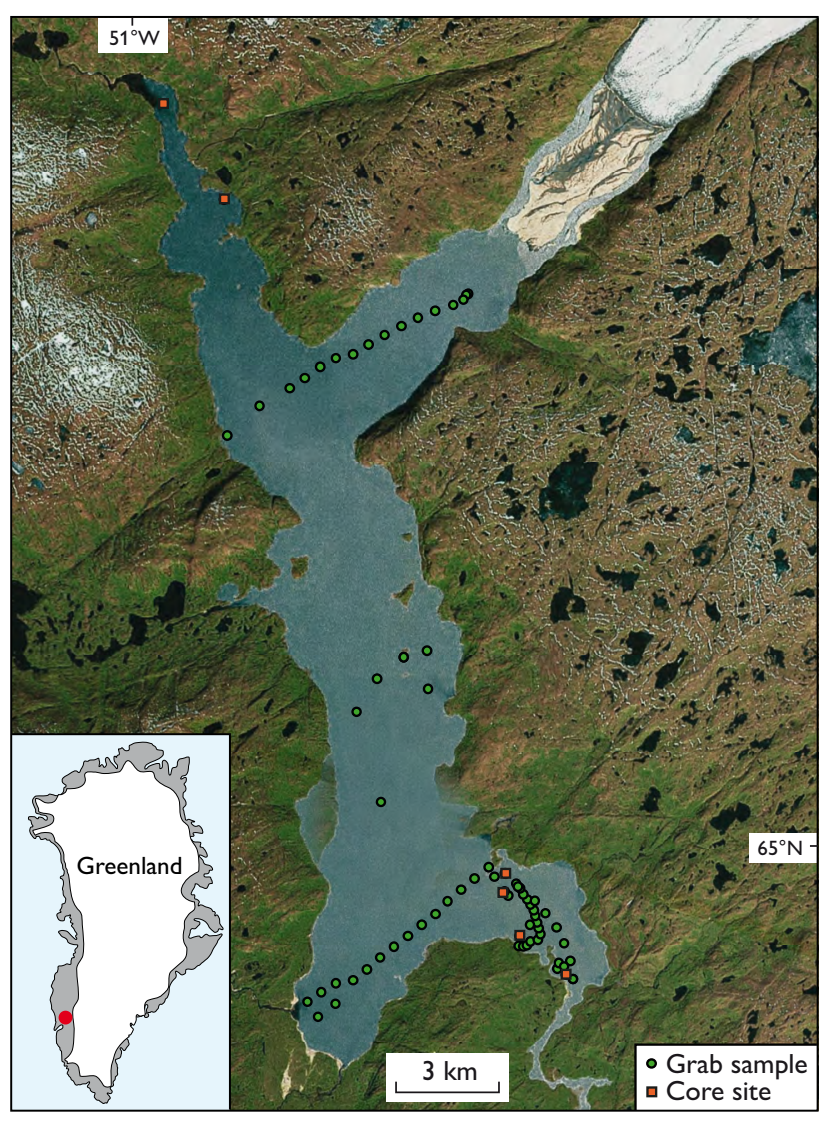

Fig. 1. Satellite image of the Tasersuaq area showing sampling sites. Inset: The location of Tasersuaq in Greenland. in many areas it is not possible to increase crop production by irrigation (Wise 2013).

Large areas in the tropics are characterised by strongly depleted soils with low concentrations of nutrients such as nitrogen, phosphorous and potassium. In such areas, the yield of crop per hectare is much lower than the theoretical yield using optimal fertilising (Ray et al.2013). Reducing the gap between real and potential crop productivity offers the best solution to achieve food security for the world's rapidly growing population.

Poor soil quality in the tropics is largely due to the rapid weathering of minerals and leaching of dissolved nutrients in the warm and humid climate. If weathered minerals are not replaced by new minerals, for example due to volcanic activity, then soil fertility continues to decline over time. Therefore, it is necessary to use increasing amounts of fertilisers to feed growing populations in the tropics. Most nutrients come from geological deposits; the only exception is nitrogen, which can be extracted from the atmosphere. $\mathrm{Nu}$ trients that are mined constitute a limited resource. Hence the known occurrences of phosphorous can only cover the current demand for a few decades (van Vuuren et al. 2010).

In recent years, investigations have been conducted to see if the productivity of nutrient-poor soils can be improved by the application of glacial rock flour from Greenland. Rock flour in southern West Greenland consists of fine-grained silt, formed by the grinding of bedrock by stones and boulders embedded in the basal part of glaciers. Preliminary results indicate that plants cultivated in soils with rock flour can achieve increased growth (M.T. Rosing, unpublished data 2019). However, the research is still in its early days and many questions remain. We do not know why adding rock flour to soil results in increased growth. Maybe the silt fraction improves the soil properties. Also we do not know if it is feasible to mine rock flour and transport it to the tropics. As a first step towards answering some of these questions, our aim here was to simply map and sample the glacial rock 

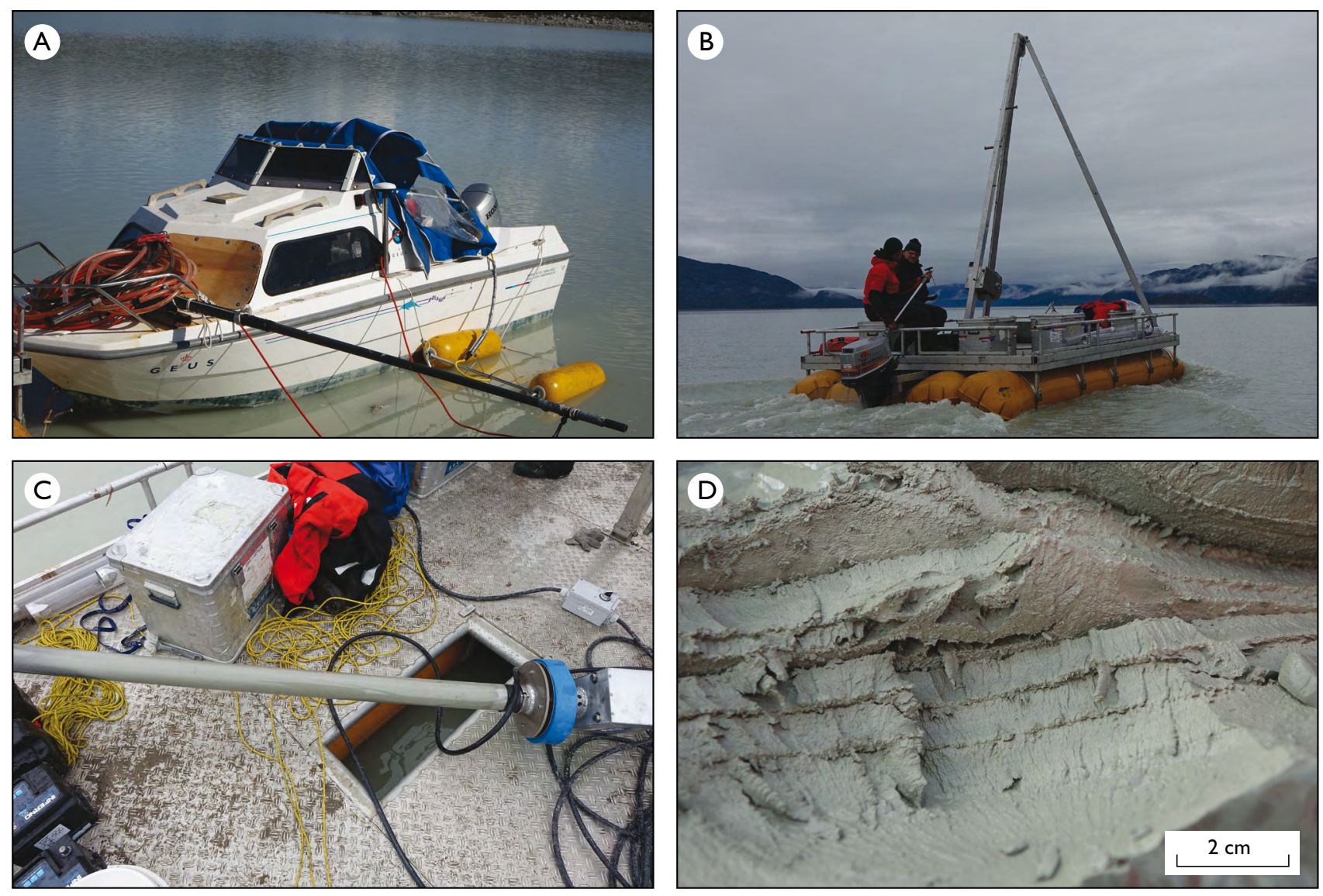

Fig. 2. Photographs from the field work. A: The GEUS II speedboat with the streamer on the foremost part of the boat and the two C-boom floats in the water. B: Deploying the coring platform on Lake Tasersuaq. C: The vibrocore with a grey sediment core in the tube, on the deck of the coring platform. D: Layered, probably varved, silt and clay sediments retrieved from the lake floor.

flour in Tasersuaq, a large proglacial lake in southern West Greenland, c. $105 \mathrm{~km}$ north-east of Nuuk.

\section{Lake Tasersuaq}

The area surrounding Lake Tasersuaq $\left(65^{\circ} \mathrm{N}, 50.8^{\circ} \mathrm{W}\right)$ is characterised by large U-shaped valleys and ice-scoured rounded mountains that reach elevations of 600 to $800 \mathrm{~m}$ asl. The bedrock geology is dominated by Archaean basement rocks, mainly Qôrqut granite (Escher \& Pulvertaft 1995).

The lake is $30 \mathrm{~km}$ long, $2-3 \mathrm{~km}$ wide and has an irregular shape (Fig. 1). The elevation of the lake is $74 \mathrm{~m}$ above sea level, which is close to the local marine limit (i.e. the limit of raised marine deposits). However, we did not observe any marine deposits, suggesting that the lake threshold is above the marine limit and thus the deposits are free from $\mathrm{NaCl}$, which is toxic to many plants. A $28 \mathrm{~km}$ long, land-based outlet glacier, Saqqap Sermersua, from the Greenland ice sheet almost reaches a north-eastern branch of the lake, but is separated by a sandur plain and delta. There are no fresh, unvegetated moraines or trim line zone bordering the glacier, which appears to have advanced in recent centuries (Weidick et al. 2012). Huge amounts of meltwater drain into Tasersuaq and the lake water is highly turbid.

To the south-west of the lake is a large plain, Narsarsuaq, which mainly consists of glaciofluvial sand and some gravel that was deposited during the last deglaciation of the region, when lake Tasersuaq was still filled by glacier ice and meltwater drained towards the south-west. Several low U-shaped moraine ridges are found on the plain (Weidick 1971); they mark stillstands or minor re-advances during periods of ice retreat. A number of distinct kame terraces are found at the south-eastern end of the lake, probably formed by a thinning glacier lobe in the lake basin. The terraces were mapped as ice margin deposits by Weidick (1978).

Larsen et al. (2014) assigned the ice margin deposits in the Tasersuaq area to the Kapisigdlit stade - a Holocene glacial stade, which they suggested has an age of 10.1-10.4 ka BP. From this and ${ }^{10} \mathrm{Be}$ exposure ages obtained from the region by Larsen et al. (2014), we suggest that the Tasersuaq lake basin was deglaciated shortly after $10 \mathrm{ka} B P$. 


\section{Methods}

In 2018, we carried out echo sounding, seismic profiling, grab sampling and coring at lake Tasersuaq. The acoustic work was conducted mainly onboard the GEUS II speedboat (Fig. 2A). The boat was equipped with a GPS system for precise positioning and a Navisound 215 echo sounder to measure water depth down to about $100 \mathrm{~m}$. For seismic profiling we used a C-Boom seismic source and a Geo-Sense Ministreamer, with a frequency band of $0.5-1.5 \mathrm{kHz}$. A resolution of $c .30 \mathrm{~cm}$ can be achieved, and the penetration was about $50 \mathrm{~m}$. The streamer was kept $4 \mathrm{~m}$ from the propeller wash by a glass fibre rod. For the acquisition of the seismic data we used a Chesapeake Technology 24 bit AD converter and for run line management, recording and processing of seismic data we used Chesapeake SonarWiz 6.

Sediment sampling was conducted from a Uwitec coring platform kept afloat by four inflatable tubes (Fig. 2B). The platform had a payload of $2600 \mathrm{~kg}$ and a $4 \mathrm{~m}$ high tripod and winch, which was used to pull the sediment cores up from the lake floor. We mounted a $25 \mathrm{HP}$ outboard motor for transportation of the platform on the lake. A small zodiac dinghy was used for transport between the shore and the platform - and for safety as a man-over-board boat.

We collected a total of 63 grab samples and seven sediment cores, noting their position with a hand-held GPS. Grab samples were collected using a small van Veen sampler. Often, we only retrieved small samples due to the stiff nature of the sediments and so we collected multiple samples at each site to get enough sediment for analysis. Sediment cores were collected using a VibeCore-D developed by SDI Speciality Devices. The corer consists of a battery-operated vibrating core head, a weight ring and a core tube and works by vibrating core tubes down into the sediments. The sediment cores are kept in the tubes by valves in the core head and by core catchers. We collected $2 \mathrm{~m}$ long, $7.6 \mathrm{~cm}$ diameter sediment cores, using polycarbonate core tubes (Fig. 2C). All sediment
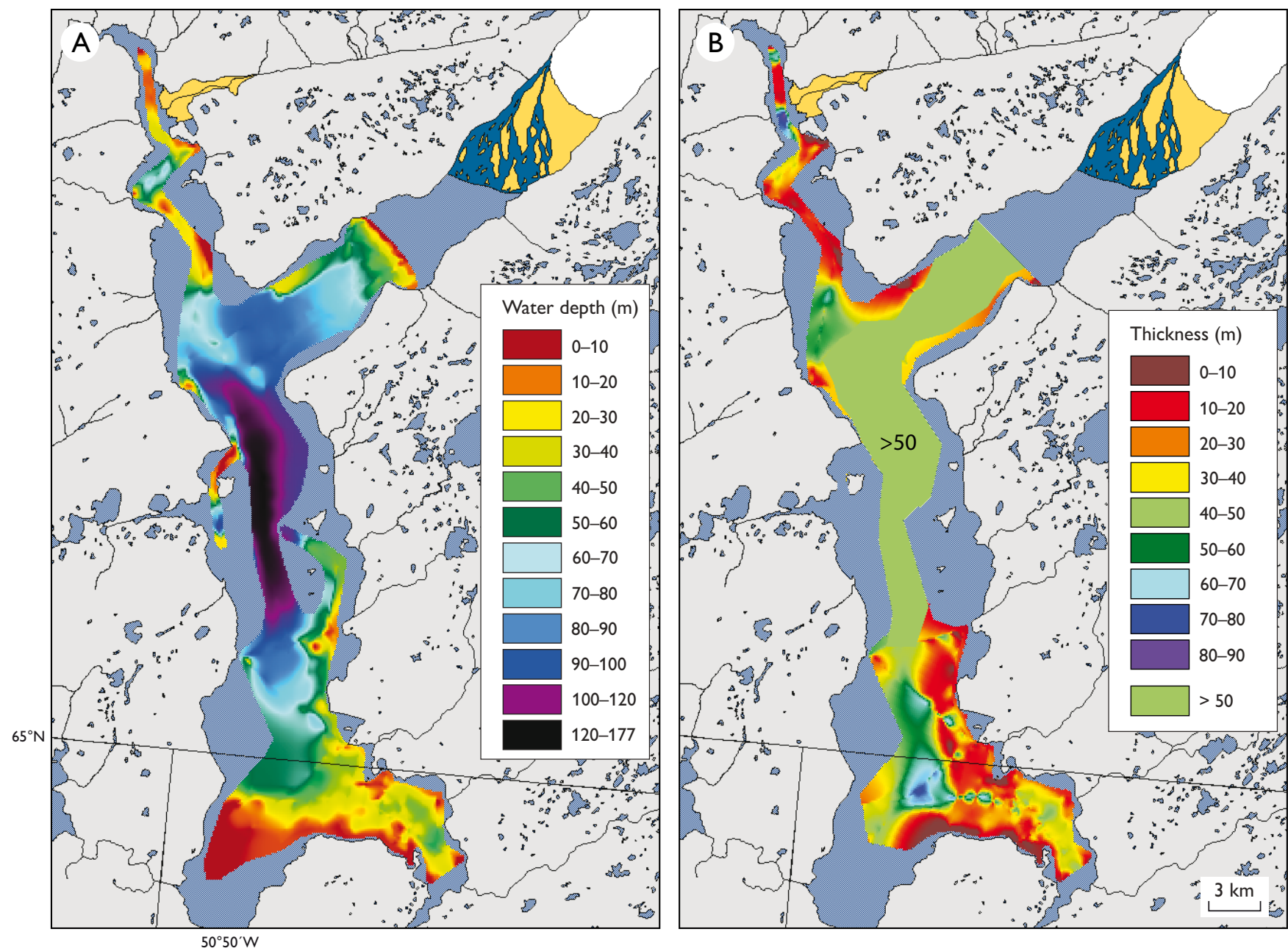

Fig. 3. A: Bathymetry of Lake Tasersuaq determined from echo sounder and C-boom seismic profiles. B: Sediment thickness. The area marked with '> 50' indicates sediment thickness greater than $50 \mathrm{~m}$. Here, the boomer signal could not penetrate the sediment succession any farther and so the exact thickness could not be determined. 
samples and cores were reserved for analyses at a later date, to characterise their grain size distributions, mineralogical and elemental compositions. Here, we focus only on the mapping of sediments.

\section{Results and discussion}

The southern and northern parts of Tasersuaq are relatively shallow, with water depths generally below $c .40 \mathrm{~m}$, and just 5-10 $\mathrm{m}$ in the south-west (Fig. 3A). Water depth off the sandur plain and delta in front of the Saqqap Sermersua glacier increases rapidly, reaching $177 \mathrm{~m}$ in the central north-southorientated part of the lake.
Glacial rock flour is found in most parts of the lake, but sandy sediments dominate the delta in front of Saqqap Sermersua. Sandy sediments were also found on the lake floor in front of the delta, at water depths up to $30 \mathrm{~m}$. Deposition of sand in such deep waters is probably due to strong bottom currents. Sandy sediments also dominate the shallow southwestern branch of Tasersuaq and we suggest that they represent glaciofluvial sediments that accumulated during the last deglaciation. A thin layer of glacial rock flour was found at some sampling sites in the south-west, but this fine-grained material is probably eroded and redeposited in deeper waters during stormy weather.
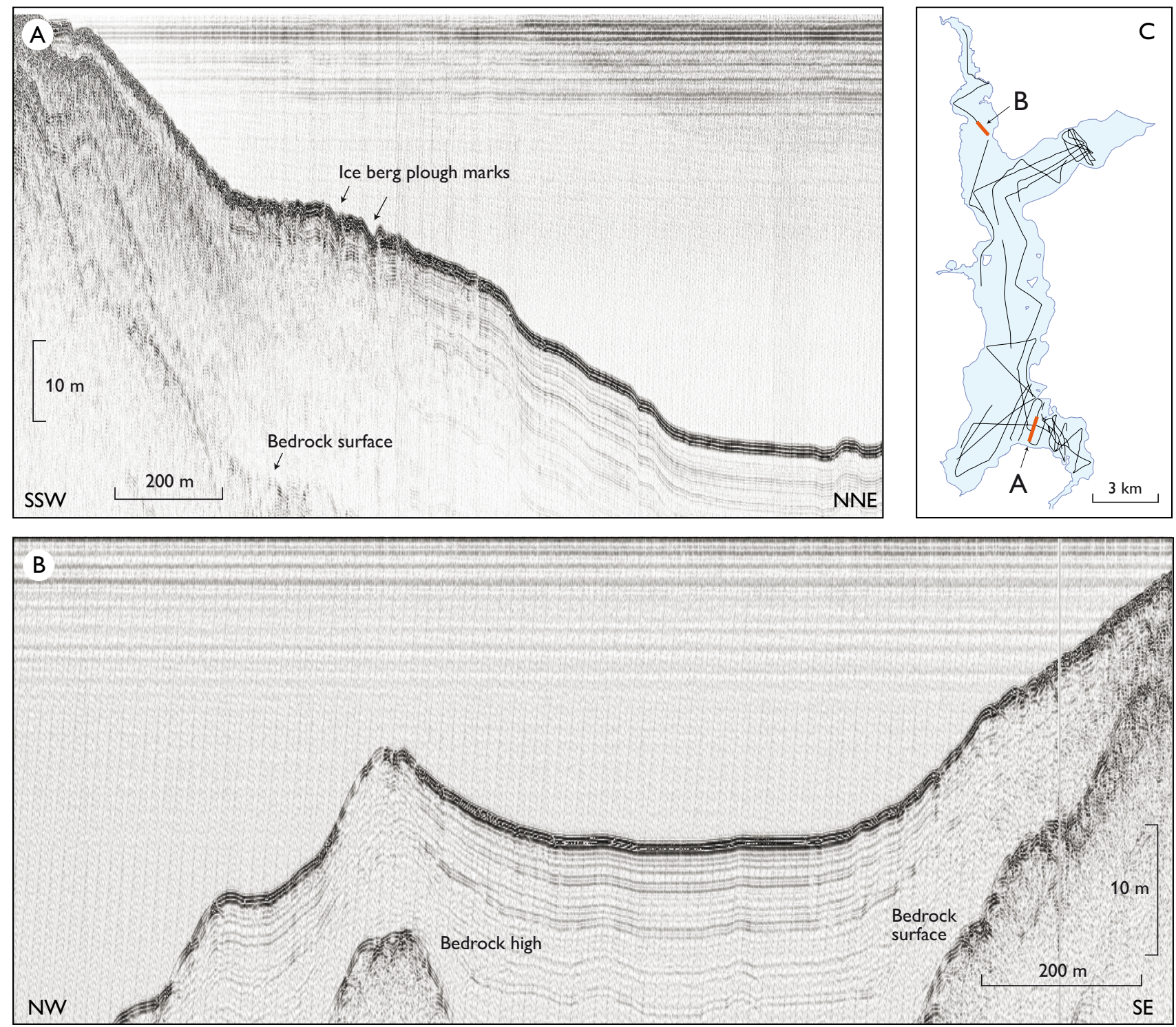

Fig. 4. Two examples of seismic profiles from Lake Tasersuaq. A: Line 0004, B: Line 0013. C: Location of seismic data aquired in 2018 and the location of the seismic profiles shown in A and B. 
In front of the delta, numerous branches and twigs were observed to be floating on the water. We speculated as to whether they were recent, having been eroded by rivers during the growth of the glacier - or if they were Mid-Holocene, from a time when the Greenland ice sheet was smaller than at present (Briner et al. 2016). Radiocarbon dating yielded modern ages (not shown) indicating that the plant remains are modern.

In the deeper parts of the lake, more than $50 \mathrm{~m}$ of sediments have accumulated (Fig. 3B). If we assume that sedimentation began $c .10 \mathrm{ka}$ ago, this would correspond to a mean sedimentation rate of $0.5 \mathrm{~cm}$ per year, which we consider typical for a proglacial lake. The lake is frozen for most of the year but ice-free in the summer. Its large size and location near the margin of the ice sheet, means that strong winds can develop over the water, leading to fairly large waves, which prevent fine-grained sediments from accumulating in shallow areas. The sediments appear acoustically laminated (Fig. 2D) with parallel reflections in the seismic profiles and the sediments drape over the underlying irregular bedrock surface (Fig. 4).

Plough marks are visible in some seismic profiles, at depths of up to $c .40 \mathrm{~m}$ (Fig. 4A). No icebergs occur in the lake at present, which might otherwise have caused the plough marks. However, a local hunter who visited the area in 1862 and 1865 noted the presence of icebergs in the lake, hence the glacier was calving into the lake at that time (Barselaj 1866; Weidick et al. 2012). The plough marks are not covered by sediments and we consider it likely that they formed during the Little Ice Age.

\section{Conclusions}

Lake Tasersuaq contains more than $50 \mathrm{~m}$ of fine-grained glacial rock flour in the deeper parts of the lake. The sediment accumulated following the last deglaciation, around 10000 years ago.

The mapping carried out in 2018 provides the first understanding of the spatial distribution and amount of rock flour deposits in the lake and forms an important first step to assessing the resource potential of these deposits in Greenland. Further work is now needed to characterise the sediments in terms of their grain size, mineralogy and chemistry and to assess the effectiveness of rock flour as a fertiliser in nutrientpoor soils.

\section{Acknowledgements}

Geocenter Denmark financed the study. Lars-Georg Rödel took care of the technical aspects of the field work. We thank the reviewers, Niels Tvis and Asger Ken Pedersen, whose comments improved the manuscript.

\section{References}

Barselej 1866: Taserssualiarnermik kingornalo angalanermik tusagagssiat (Account from a voyage to the Taserssuaq area). The newspaper Atuagagdliutit, 30 November, columns $1238-1240$ and 8 December, columns 1246-1251.

Briner, J.P. et al. 2016: Holocene climate change in Arctic Canada and Greenland. Quaternary Science Reviews 147, 340-364. https://doi. org/10.1016/j.quascirev.2016.02.010

Escher, J.C. \& Pulvertaft, T.C.R. 1995: Geological map of Greenland 1: 2 500 000. Copenhagen: Geological Survey of Greenland.

Larsen, N.K., Funder, S., Kjær, K.H., Kjeldsen, K.K., Knudsen, M.F. \& Linge, H. 2014: Rapid early Holocene ice retreat in West Greenland. Quaternary Science Reviews 92, 310-323. https://doi.org/10.1016/j. quascirev.2013.05.027

Ray, D.K., Müller, N.D., West, P.C. \& Foley, J.A. 2013: Yield trends are insufficient to double global crop production by 2050. PLOS ONE $\mathbf{8}$, e66428. https://doi.org/10.1371/journal.pone.0066428

Van Vuuren, D.P., Bouwman, A.F. \& Beusen, A.H.W. 2010: Phosphorus demand for the 1970-2100 period: A scenario analysis of resource depletion. Global Environmental Change 20, 428-439. https://doi. org/10.1016/j.gloenvcha.2010.04.004

Weidick, A. 1971: Quaternary map of Greenland, 1:2 500 000. Copenhagen: Geological Survey of Greenland.

Weidick, A. 1978: Kvartærgeologisk kort over Grønland, Frederikshåbs Isblink - Søndre Strømfjord, 1:500 000. Copenhagen: Geological Survey of Greenland.

Weidick, A., Bennike, O., Citterio, M. \& Nørgaard-Pedersen, N. 2012: Neoglacial and historical glacier changes around Kangersuneq fjord in southern West Greenland. Geological Survey of Denmark and Greenland Bulletin 27,68 pp.

Wise, T.A. 2013: Can we feed the World in 2050? A scoping paper to assess the evidence. Global Development and Environment Institute working paper 13-04, 36 pp. Medford: Tufts University.

\section{How to cite}

Bennike, O., Jensen, J.B, Sukstorf, F.N. \& Rosing, M.T. 2019: Mapping glacial rock flour deposits in Tasersuaq, southern West Greenland. Geological Survey of Denmark and Greenland Bulletin 43, e2019430206. https://doi.org/10.34194/GEUSB-201943-02-06

\footnotetext{
${ }^{*}$ Corresponding Author: Ole Bennike |E-mail: obe@geus.dk

${ }^{1}$ Geological Survey of Denmark and Greenland (GEUS), C.F. Mollers Allé 8, DK-8000, Aarbus C, Denmark

${ }^{2}$ Department of Geosciences and Natural Resource Management, University of Copenhagen, Øster Voldgade 10, DK-1350 Copenhagen K, Denmark

${ }^{3}$ Department of Biology, University of Copenhagen, Øster Voldgade 5-7, DK-1350 Copenhagen K, Denmark.
} 